European Identity and Citizenship 

Sanja Ivic

\section{European Identity and Citizenship}

Between Modernity and Postmodernity 
Sanja Ivic

Institute of International Relations

Prague, Czech Republic

Institute for European Studies

Belgrade, Serbia

ISBN 978-1-137-57784-9

ISBN 978-1-137-57785-6 (eBook)

DOI $10.1057 / 978-1-137-57785-6$

Library of Congress Control Number: 2016940185

(C) The Editor(s) (if applicable) and The Author(s) 2016

The author has asserted her right to be identified as the author of this work in accordance with the Copyright, Designs and Patents Act 1988.

This work is subject to copyright. All rights are solely and exclusively licensed by the Publisher, whether the whole or part of the material is concerned, specifically the rights of translation, reprinting, reuse of illustrations, recitation, broadcasting, reproduction on microfilms or in any other physical way, and transmission or information storage and retrieval, electronic adaptation, computer software, or by similar or dissimilar methodology now known or hereafter developed.

The use of general descriptive names, registered names, trademarks, service marks, etc. in this publication does not imply, even in the absence of a specific statement, that such names are exempt from the relevant protective laws and regulations and therefore free for general use.

The publisher and the author are safe to assume that the advice and information in this book are believed to be true and accurate at the date of publication. Neither the publisher nor the author give a warranty, express or implied, with respect to the material contained herein or for any errors or omissions that may have been made.

Printed on acid-free paper

This Palgrave Macmillan imprint is published by Springer Nature The registered company is Macmillan Publishers Ltd. London 


\section{Contents}

1 Introduction 1

Bibliography 14

2 Modernist and Postmodernist Accounts of Identity 19

2.1 Introduction 19

2.2 Hermeneutic Approaches to Subjectivity 25

2.2.1 The Modernist Conception of Identity:

Descartes's and Locke's Accounts of Identity 27

2.3 The Critique of the Modernist Idea of Subjectivity: Hume and Feminist Thinkers on Identity 34

2.4 Paul Ricoeur's Hermeneutics of Suspicion as a Critique of the Modernist Concept of Identity 39

2.5 Poststructuralist and Postmodernist Concepts of Identity

2.6 Conclusion $\quad 58$

Bibliography $\quad 59$

3 Philosophical Roots of Citizenship 65

3.1 Introduction $\quad 65$

3.2 Aristotle's Conception of Citizenship:

Citizenship as Active Participation 
3.3 The Modern Liberal Concept of Citizenship

3.3.1 The Enlightenment Roots of Citizenship and Human Rights Discourse

3.3.2 T. H. Marshall's Concept of Citizenship

3.4 Postmodern and Postnational Concepts

of Citizenship

3.4.1 Postmodern Legal and Political Theory

3.4.2 Postmodern and Postnational Notions of Citizenship

3.5 New Ethics of Citizenship: The Ethics of Care

3.5.1 An Ethics of Care: From Feminist Theory to the Idea of Contextual Morality

3.5.2 Ethics of Care as the Basis of

Deliberative Democracy

3.5.3 The Autonomy of the Personality as the Fundamental Idea of the Ethics of Care and Deliberative Democracy

3.6 Conclusion

Bibliography

4 The Concept of European Citizenship

4.1 Introduction

4.2 EU Citizenship: Towards a Postmodern

Concept of Citizenship?

4.2.1 Postmodern and Postnational Traits of the European Union, and EU Citizenship

4.2.2 The First Decade of EU Citizenship:

EU Politics as a Reflection of the Modernist Politics of Identity

4.3 EU Citizenship as a Mental Construct:

Mental Maps of Keeping In and Keeping Out

4.3.1 The Second Decade of EU Citizenship: Towards a Postmodern Conception of Citizenship? 
4.4 Poststructuralist Feminist Critique

of European Law

4.4.1 The Problem of Discrimination against Women in European Union

4.4.2 The Concept of 'Family' in European Law

4.5 The Concept of EU Citizenship within

European Public Discourse

166

4.5.1 The European Commission's Plan D

for Democracy, Dialogue and Debate

167

4.5.2 Deliberative Democracy as a Key to the 'Democratic Deficit' in Europe

168

4.6 Plan D for Democracy, Dialogue and Debate

4.6.1 Critique of Plan D for Democracy, Dialogue and Debate: Deliberation versus Debate

4.6.2 Discursive Production of 'European

Public Sphere,' 'European Identity, and 'European Values'

4.6.3 The European Year of Citizens

4.6.4 Metaphysical Origins of Europeanness:

Creating Narratives for Europe

180

4.7 Demographic Change in the European

Union: A Challenge to EU Citizenship

and European Identity

182

4.7.1 Rights of Older Adults within

EU Legal Discourse

4.7.2 The Obstacles to Development of Active EU Citizenship

4.8 Conclusion

Bibliography

\section{The European Identity}

5.1 Introduction

5.2 The Concept of European Identity 
5.3 The Four Values of the Charter of Fundamental

Rights of the European Union

5.3.1 Metaphysical Presuppositions of the Charter of Fundamental Rights of the European Union 217

5.3.2 The Four Values: Dignity, Freedoms, Equality, and Solidarity

5.4 Poststructuralist Understanding of European Identity

5.4.1 Section A of the Udine DeclarationTowards the Logic of Heterogeneity?

5.4.2 Section C of the Udine DeclarationTowards the Logic of Homogeneity?

5.4.3 European Identity and European Values in a Time of Crisis

5.5 The EU Visa Liberalization Process

for Western Balkan Countries as a Reflection of the Politics of Modernity

5.5.1 The Postmodern Account of Identity and Difference

5.5.2 The EU Visa Liberalization Process for Western Balkans Binaries

5.6 Conclusion

Bibliography 


\section{List of Tables}

Table 2.1 Modernist and postmodernist accounts of identity

Table 3.1 Modern, Postnational and Postmodern Notions of Citizenship 96 